\title{
LAAT VAREN ALLE HOOP, GIJ DIE HIER BINNENTREEDT
}

Stephen Emmot, Tien Miljard. Kan de aarde de mensheid nog aan? Amsterdam, Atlas Contact, 2013, 198 pp., € 12.50 ISBN 9789045024608

Indien optimisme werkelijk een morele plicht is, dan zou je kunnen stellen dat Stephen Emmott, hoofd van de afdeling computationele wetenschap van Microsoft research, een immorele wetenschapper is. In zijn boek Tien Miljard bekijkt hij de heikele overbevolkingskwestie in elk geval niet bepaald door een roze bril. Waar Peter Diamandis en Steven Kotler in hun Abundance: The Future Is Better Than You Think (2012) een tijd van overvloed zien aanbreken en anderen heil zien in zingen voor het klimaat, concludeert Emmott boudweg dat we, al dan niet zingend, al met één been boven de spreekwoordelijke afgrond zweven. De boodschap die hij daar impliciet aan verbindt is zelfs ronduit sinister: leer je kinderen omgaan met een geweer. Kortom: een wereld, bevolkt met tien miljard mensen, wordt een danteske hel. Ze kreunt nu al in al haar voegen, wanneer we straks met tien miljard of meer zijn, barst ze onherroepelijk uit die voegen. Daarmee vertelt Emmott natuurlijk niets nieuws. Zijn boek past perfect in de lange, donkere traditie van historisch en cultureel pessimisme die Arthur Herman beschrijft in The Idea of Decline in Western History (2007) en, meer specifiek, in een reeks van eco-alarmistische werken uit de jaren zestig en zeventig van de vorige eeuw. Laten we het echter optimistisch bekijken: qua lay-out is het wel een verfrissend buitenbeentje. Trouwens, in een recent interview met New Scientist bekent Emmott dat hij de hoop op een oplossing dan toch niet opgegeven heeft aangezien zijn laboratorium onderzoek doet naar zaken als artificiële fotosynthese en technologieën die een nieuwe voedselrevolutie mogelijk moeten ma-ken.' Hetzelfde laboratorium waarnaar hij verwijst aan het begin van zijn "doomsday" boek. Het probeert inzicht te verkrijgen in ecosystemen, stelt hij, en te voorspellen hoe die systemen zullen reageren op "veranderingen." "Veranderingen," heet het onheilspellend, "die wij veroorzaakt hebben."

Overbevolkingsvrees - er zou inderdaad een woord voor moeten bestaan - is wellicht zo oud als de mens zelf. Jagers en verzamelaars hielden hun populatie hoogstwaarschijnlijk tot op zekere hoogte onder controle via praktijken als infanticide, neonaticide en geronticide. Met de neolithische revolutie begon de menselijke populatie sneller te groeien. We controleerden in toenemende mate de natuur of de niet-menselijke natuur, veeleer dan menselijke populaties. Wat natuurlijk niet betekent dat overbevolkingsbesognes en praktijken als infanticide helemaal verdwenen. Wellicht werd het vermogen van de mens om, dankzij steeds betere landbouwtechnieken en een almaar toenemend landbouwareaal, de stijgende bevolking te voeden, altijd al in vraag gesteld. Aristoteles zag een 
bijkomend potentieel onheil in een al te snel groeiende populatie: mogelijke problemen met de ordehandhaving. Net zoals Plato raadde hij overheden een strikt fertiliteitsbeleid aan. Zes eeuwen later was de situatie blijkbaar nog altijd even ernstig: in de tweede eeuw na Christus declareerde de kerkvader Tertullianus plechtig dat het groeiend aantal mensen een last voor de aarde was.

In zijn Le poids du nombre - L'Obsession du surpeuplement dans l'histoire (2011) ziet Georges Minois Thomas Malthus' Essay on the Principle of Population (1798) als een keerpunt: vanaf toen kreeg de overbevolkingsvrees een existentieel tintje. Het was dan ook zeer goed getimed. De industriële revolutie luidde namelijk niet alleen een exponentiële groei van de menselijke bevolking in maar meteen ook een steeds meer vervaarlijke of vervaarlijk ogende milieu- en, tegen het einde van de vorige eeuw, klimaat- en grondstoffenproblematiek. Publicaties als Rachel Carsons Silent Spring (1962), Paul Ehrlichs The Population Bomb (1968) en het rapport The Limits to Growth (1972) van de Club van Rome speelden een sleutelrol in de groeiende bewustwording van dit kluwen van problemen. Ook de publicatie van de eerste NASA-foto's van onze blauwe planeet hadden een belangrijk effect. Matt Ridley wijst er in zijn The Rational Optimist: How Prosperity Evolves (2011) op dat zowel Malthus als Ehrlich ongelijk gekregen hebben. We werden inderdaad niet geconfronteerd met de massale hongers-noden en honderden miljoenen doden waar die laatste voor waarschuwde. Emmott reageert op zijn beurt op Ridley. Hij noemt zichzelf een rationele pessimist en neemt Ridley's these dat technologie ons opnieuw zal redden op de korrel. In groene energie, het ontzilten van zeewater, geoengineering en een tweede groene revolutie gelooft hij niet. In kernenergie wel, maar een wereldwijd programma voor kernenergie zit er niet direct aan te komen. Het soort gedragswijzigingen waar beroemdheden graag mee uitpakken, genre een elektrische auto kopen of onder de douche plassen (zijn favoriet), doet hij af als pietluttig. We moeten eenvoudigweg veel minder consumeren en stoppen met ons reproduceren. Dat laatste voorstel vindt hij, eigenaardig genoeg, "volslagen belachelijk" aangezien het een van onze belangrijkste en leukste impulsen is. Het eerste zal evenmin gebeuren. Vandaar zijn conclusie: we are fucked of, in deftig (alhoewel) Noord-Nederlands: we zijn de lul.

Het boek lokt heel tegenstrijdige reacties uit, of wat had U gedacht. Chris Goodall noemt het in de Guardian onwetenschappelijk en misantropisch, John Gray, de zogenaamde poster jongen van de misantropen, heeft het in dezelfde krant over een onmisbaar boek. Die uiteenlopende oordelen zijn echter niet alleen te wijten aan Emmotts Schopenhaueriaanse radicaliteit. Hij brengt dan wel op een vlotte manier een duidelijke en met veel feitenmateriaal geïllustreerde boodschap, vlekkeloos is zijn verhaal niet, inhoudelijk noch vormelijk. De lay-out noemde ik verfrissend. Niet iedereen zal echter een PowerPoint-presentatie op papier kunnen appreciëren, zonder noten, bibliografie of index. Al zorgen de paar zinnen of alinea's per pagina en de vele grafieken en zwart/wit foto's die Emmott de lezer 
serveert er wel voor dat het boek leest als een sneltrein: in minder dan een uur ben je er doorheen. Het doemformat - na een paar pagina's heeft hij het al over een wereldwijde crisis die haar weerga niet kent - helpt trouwens ook om er een vlot lezend verhaal van te maken. Veel mensen hebben nu eenmaal een morbide fascinatie voor dat soort scenario's.

Sommige critici vinden het wel niet meteen de beste manier om de overbevolkingsboodschap te brengen. Emmotts compromisloze slag in het gezicht zou veeleer verdoven dan wakker schudden. Voor zover dat wakker schudden de bedoeling was (Emmott ontkent dit in het eerder vermeld interview), hebben ze misschien gelijk. Wat hem, afgaand op het groot aantal ongenuanceerde uitspraken dat het boek bevat, in elk geval wel verweten kan worden, is dat hij er iets te zeer op gebrand is die slag toe te dienen. Hier en daar gaat hij zelfs helemaal uit de bocht, al werden een aantal van die onnauwkeurigheden gecorrigeerd in de Nederlandse editie. ${ }^{2}$ Zo draagt het smelten van het Arctisch ijs gelukkig niet meer bij tot de stijging van de zeespiegel en wijkt de kustlijn in het Arctisch gebied niet meer met veetien meter per jaar terug. Vijftig miljoen hectare heet echter nog altijd ongeveer vijftig procent van West-Europa te zijn (vijftien procent is correcter, als we landen als Spanje en Noorwegen tot West-Europa rekenen). We 'leren' ook dat maar liefst veertig procent van de aarde gebruikt wordt voor landbouw en dat de piek in voedselprijzen die bijdroeg tot het revolutionaire tumult in Noord-Afrika, exclusief te wijten was aan een Russisch embargo op het uitvoeren van graan.

Het zijn vooral de alarmistische en ongenuanceerde uitspraken die storen. Het is juist dat bijna veertig procent van de ijsvrije landmassa gereserveerd is voor de landbouw maar daarvan wordt slechts een klein deel gebruikt voor het kweken van gewassen (elf procent van de totale landmassa). Dat alle landbouwgrond op aarde al in gebruik is, is een gemeenplaats: dat was 5000 jaar geleden ook al zo. Een recente studie van de FAO leert dat er nog tweemaal zoveel grond voorradig is voor landbouw als we momenteel gebruiken, al wordt bijna de helft van die reserve momenteel ingenomen door bos. ${ }^{3}$ Het klopt ook niet dat er voor geen enkel geo-engineering idee ook maar enig bewijs is dat het werkt, dat alle geoengineering projecten peperduur zijn en dat ze allemaal onvoorspelbare kettingreacties teweeg zullen brengen. Alsof het verminderen van het koolzuurgasgehalte van de atmosfeer door het planten van echte of artificiële bomen geen effect zou hebben of gevaarlijk zou zijn. Het weliswaar veel minder onschuldige nabootsen van klimaat afkoelende vulkaanuitbarstingen is zelfs spotgoedkoop: het injecteren van sulfaat-aerosolen in de stratosfeer zou slechts een miljard dollar per jaar kosten, ongeveer 0,14 procent van het overheidsdeficit van de Verenigde Staten. En neen: de voor de landbouw cruciale fosfaatvoorraden gaan niet "hoogstwaarschijnlijk" deze eeuw al uitgeput raken. De voorspellingen lopen uiteen van vijftig jaar tot meer dan 300 jaar. Bovendien betreft het hier enkel goedkoop ontmijnbaar fosfaat. De stelling dat we met ons huidig consumptiepatroon en landbouwsysteem niet in staat zijn tien miljard mensen te 


\section{5}

voeden is eveneens discutabel. Al was het maar omdat de productiviteit van de landbouw nog altijd jaar na jaar toeneemt en er in de westerse of verwesterde wereld enorm veel voedsel verspild wordt.

Het ergst is wel dat Emmott, aan de hand van heel selectieve voorbeelden, insinueert dat de bevolkingsexplosie helemaal uit de hand gaat lopen. Hij heeft het over maar liefst 28 miljard mensen tegen 2100 indien de wereldwijde bevolkingsaanwas in het huidig tempo doorgaat. In werkelijkheid - en Emmott weet dit ongetwijfeld maar al te goed - neemt de snelheid van de bevolkingsgroei op wereldvlak al geruime tijd gestaag af. ${ }^{4}$ In 2100 zullen we, volgens de re-centste schatting van de Verenigde Naties, wellicht met 10.9 miljard zijn. ${ }^{5}$ Men gaat er dus vanuit dat de snelheid van de bevolkingsgroei verder gaat verminderen en uiteindelijk zelfs licht negatief gaat worden. Sommigen, zoals de wetenschapsjournalist en schrijver Fred Pearce, hebben het zelfs al over een heuse populatiecrash. ${ }^{6}$ Anderzijds heeft Emmott het, afgezien van de overbevissing, dan weer niet over de, voor het leven op onze blauwe waterplaneet, cruciale maar snel aftakelende gezondheid van de oceanen. Vooral de verzuring is onrustwekkend. Dit fenomeen, veroorzaakt door koolzuurgas absorptie, heeft wellicht een sleutelrol gespeeld in de Perm-Trias-massa-extinctie, 250 miljoen jaar geleden. Al zal de mens nooit de 13.000 to $\mathbf{4 3 . 0 0 0}$ gigaton koolzuurgas uitstoten die vulkanen toen in de loop van een miljoen jaar de atmosfeer in spuwden. Als we erg ons best blijven doen en domweg alle fossiele 'brandstoffen' verbranden, raken we aan 5000 gigaton. De opwarming die dit veroorzaakt, zal natuurlijk wel op haar beurt zorgen voor een toenemende natuurlijke uitstoot van broeikasgassen, zoals methaan dat nu opgeslagen ligt in de permafrost.

De situatie is dus zonder meer emstig maar toch niet zo ongenuanceerd en onherroepelijk hopeloos als Emmott de lezer wil laten geloven. Hij waarschuwt er ergens voor dat 'gratis' diensten van de natuur, zoals zoet water en klimaat, in het gedrang komen. Dat klopt, maar er is geen reden om a priori de mogelijkheid te verwerpen dat we er in de toekomst zullen in slagen zelf voor drinkbaar water en een stabiel klimaat te zorgen. Net zoals we, duizenden jaren geleden, zelf in toenemende mate voedsel begonnen te produceren in plaats van enkel te leven van wat de natuur ons 'gratis' schonk. In feite is deze trend zelfs nog ouder. Op vele plaatsen op aarde is er, lang voor de neolithische transitie en wellicht mede wegens populatiedruk, een trend te zien van jacht op zich traag reproducerende mega fauna naar jacht op kleinere en zich sneller reproducerende minifauna. Andere soorten zouden het uitsterven van hun klassieke prooidieren misschien niet overleefd hebben, maar de moderne mens paste zich aan met behulp van nieuwe jachttechnieken en wapens. ${ }^{7}$

Dan Gardner onderscheidt in zijn Future Babble: Why Expert Predictions Fail - and Why We Believe Them Anyway (2011) twee soorten voorspellers: egels en vossen. Egels zijn zeer zelfverzekerd over hun boude voorspellingen maar bijna 
altijd verkeerd. Vossen zijn veel genuanceerder maar vervelend. Danny Dorling schreef met zijn Population 10 Billion (2013) een vossenversie van Emmotts egelboek en kan bijgevolg op minder media-aandacht rekenen. Hij meent dat Emmott uit is op meer geld voor zijn onderzoek. Dat is weinig waarschijnlijk, aangezien hij voor een bedrijf werkt, niet voor de overheid (al is hij wel gastprofessor in Oxford en het UCL). Wellicht koos Emmott voor een ongenuanceerde egelaanpak om dezelfde reden waarom veel klimaatzangers zich ongebreideld blijven reproduceren of zonder veel gêne naar verre, exotische plaatsen vliegen: omdat hij dat, zoals al de doemdenkers die hem vooraf gingen, op een morbide manier leuk vond.

Koen TANGHE (Gent)

Noten:

1 O'Callaghan, T. 'Can the planet survive 10 billion people?', in New Scientist (2012): http:-//www.newscientist.com/blogs/culturelab/2012/07/tiffany-ocallaghan-culturelabeditor-befo-re-packed.html.

2 Zie, voor een volledige lijst van de correcties: http://research.microsoft.com/en-us/people/semmott/tenbillionbookrevisions.pdf.

3 FAO, 'World agriculture: towards 2015/2030' (2002):

http://www.fao.org/fileadmin/user_u-pload/esag/docs/y4252e.pdf.

$4 \mathrm{Zie}$ in dit verband:

http://en.wikipedia.org/wiki/File:World_population_growth_rates_1800-2005.png.

5 UN, 'World Population Prospects: The 2012 Revision' (2013):

http://www.un.org/en/devel-opment/desa/publications/world-population-prospects-the-

2012-revision.html.

6 Pearce, F. The Coming Population Crash and Our Planet's Surprising Future, Boston, Beacon, 2010.

7 Het is mogelijk dat dit de oorzaak of een van de oorzaken was van het uitsterven van de neanderthaler in Europa. 